\title{
Inter-annual and inter-decadal variability of dry days in Argentina
}

\author{
Juan Antonio Rivera, ${ }^{a, b *}$ Olga Clorinda Penalba ${ }^{b}$ and María Laura Betolli ${ }^{a}$, \\ a Departamento de Ciencias de la Atmósfera y los Océanos, Facultad de Ciencias Exactas y Naturales, Universidad de Buenos Aires, Intendente \\ Güiraldes 2160, Pabellón 2, 2॰ Piso - Cuidad Universitaria, C1428EGA Buenos Aires, Argentina \\ b Consejo Nacional de Investigaciones Científicas y Técnicas (CONICET), Av. Rivadavia 1917, C1033AAJ Buenos Aires, Argentina
}

\begin{abstract}
This work proposes to employ the number of dry days (days without precipitation) as a variable of study, and to analyse their spatial and temporal variability in Argentina. Climatological aspects of dry days, such as their annual mean values and its seasonal cycle, were discussed and compared with precipitation features in the country. Linear trends in the annual number of dry days (ANDD) were identified for the period 1960-2005. Most of the regions exhibited decreasing trends, but few stations showed significant ones. The most important trends were present in the Central-West region and over the Patagonian coast and their magnitudes indicated a decrease of two to six dry days per decade. These trends coincide with the observed increase of accumulated precipitation in part of the country during the second half of the 20th century. To identify long-term fluctuations in the ANDD, a low pass filter, a wavelet analysis and a cubic polynomial fit was applied to the longest time series of the selected locations. Through these methodologies, periodicities were identified in the inter-annual and inter-decadal ranges for the last 80 years. The most important significant cycles were observed in the range of 10-24 years, but also, depending on the region, significant inter-annual variations were found. Copyright (c) 2012 Royal Meteorological Society
\end{abstract}

KEY WORDS dry days; climatology; linear trends; wavelet analysis; Argentina

Received 3 May 2011; Revised 22 February 2012; Accepted 25 February 2012

\section{Introduction}

Climate variability creates conditions that may exceed the adaptive capacity of the activities that depend on it, and this can be a source of social problems and economic losses. The Fourth Assessment Report of the Intergovernmental Panel on Climate Change mentions that the increased variability of precipitation is one of the most important aspects related to climate change (Solomon et al., 2007). In recent years, floods and droughts have been experienced with higher peaks and severity levels (Mishra and Singh, 2010). Particularly in Argentina, the main impacts related to climate are due to the inter-annual variability of precipitation, manifested by periods of drought and floods (Barros et al., 2008). Also, long-term variabilities have affected the country during the second half of the 20th century. The studies of Minetti et al. (2003), Penalba and Vargas (2004), Pasquini et al. (2006) and Barros et al. (2008) revealed increases of precipitation over the Southeastern South America. In the Central and Northern portions of Argentina it was found large precipitation increases after 1960 (Castañeda and Barros, 2001). In consequence,

\footnotetext{
* Correspondence to: J. A. Rivera, Departamento de Ciencias de la Atmósfera y los Océanos, Facultad de Ciencias Exactas y Naturales, Universidad de Buenos Aires, Intendente Güiraldes 2160, Pabellón 2 $2^{\circ}$ Piso - Cuidad Universitaria, C1428EGA Buenos Aires, Argentina. E-mail: jrivera@at.fcen.uba.ar
}

these positive trends in precipitation have favoured the westward extension of the agricultural frontier, increasing the availability of productive lands by more than $100000 \mathrm{~km}^{2}$ (Barros et al., 2008). The changes in precipitation trigger new characteristics of drought and floods in affected regions, especially on spatial distribution and temporal patterns (Zhai and Feng, 2009). These changes often occur on spatial scales that are not detected by the majority of the global climate models and require an appropriate regional analysis (Logan et al., 2010). Some way to evaluate changes in rainfall characteristics is to analyse the number of dry days, which are important to assess impacts on net water balance (Cullen et al., 2009). The study of dry days is also significant because of the impacts these have on the functioning of different ecosystems, directly affecting the availability of a resource as necessary as water (Penalba and Llano, 2008). A higher number of dry days over a season or a year in certain regions could trigger drought conditions, as the lack of precipitation is a key factor on that process. Therefore, a thorough knowledge of the temporal variabilities in the number of dry days can be useful to complement the results of precipitation totals and heavy rains and to contribute to understand how precipitation is changing in the region.

Much of the analysis of this variable in Argentina has been centred on the study of the temporal variability of dry sequences (Penalba and Llano, 2008) and the 
fitting of theoretical distributions to the dry sequences (Boulanger et al., 2007). At present, the Department of Hydrometeorology of the National Meteorological Service (Servicio Meteorológico Nacional) develops maps of the spatial distribution of dry days for different time scales with the purpose of monitoring the occurrence and duration of the dry and wet periods in Argentina and La Plata Basin, one of the largest basins and producers of hydroelectric power in the world. Model outputs used to calculate the changes in consecutive dry days, one of the extreme indices developed by Frich et al. (2002). However, there is a lack of a climatology for dry days over Argentina in order to get better conclusions of these model outputs. In this context, this work aims to develop a climatology of dry days for the country and to analyse the inter-annual and inter-decadal variability of the annual number of dry days (ANDD) along the different climatic regions.

\section{Datasets and methodology}

Precipitation daily data for 129 stations located throughout Argentina provided by the National Meteorological Service were used in this study. This data set was preprocessed to obtain a network of stations with consistent and homogeneous records; in order to achieve stable and representative statistical results. The density of stations was irregular and larger concentration of them appeared in the vicinity of Buenos Aires City, capital city of the country, and other big cities. To reduce redundant information, we decided to eliminate stations in these regions. A large number of stations had deficiencies in the temporal coverage of their records, either because their length was too short for climatological analysis, or because they presented several gaps in their time series. Few stations had discontinuities in their records because of changes in their location and were also discarded for the analysis. Quality control analyses like the elimination of negative precipitation values and the evaluation of the length of consecutive dry days were performed. These analysis identified inconsistencies in observing practices at several locations. Finally, the stations with more than $10 \%$ of missing daily values for the period 1960-2005 were rejected. This period was chosen since it is the longest period available that permits analysing a large number of stations. After the quality control procedure, 46 stations were selected for the study (Figure 1, Table I).

On the basis of this high quality database, the number of dry days was calculated on monthly and annual scales. Various thresholds were used for daily precipitation to define a dry day, for example, 0 and $2 \mathrm{~mm}$. Both thresholds were compared by Penalba and Llano (2008) for the analysis of dry sequences in the agricultural zone of Argentina without any substantial differences. In this work, we defined a dry day as a day with zero accumulated precipitation. Gap-filling routines were applied occasionally to stations with an entire missing month. These months were filled with its climatological mean value.

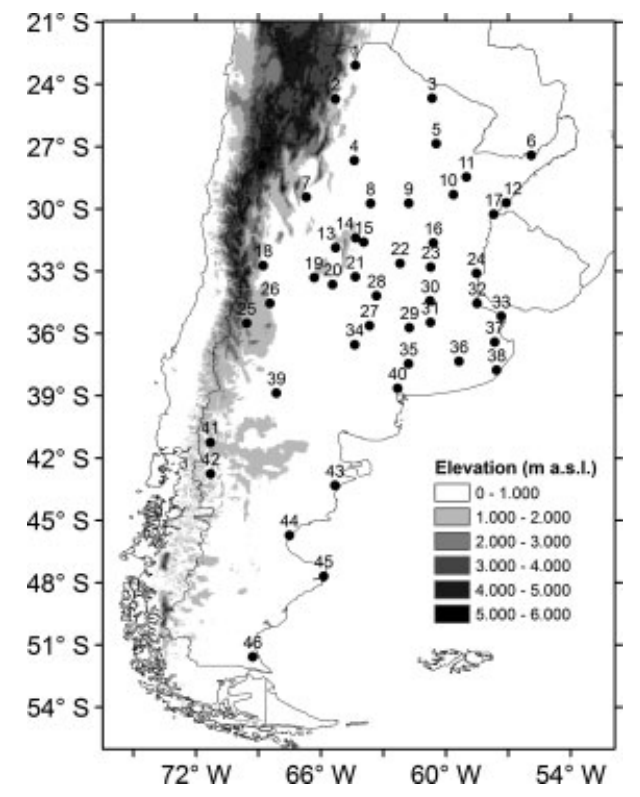

Figure 1. Geographical locations of the meteorological stations used, together with the elevation in the study area.

For the analysis of the seasonal variations, the 12 monthly mean number of dry days were subjected to harmonic analysis. This method was described in detail by Panofsky and Brier (1958).

The linear trends were calculated for the period 1960-2005. A straight line was adjusted to each time series by using the linear regression method of least squares. The adjustment was evaluated by the correlation coefficient of Pearson, $r$, which reflects the degree of lineal dependency between two data sets. The significance of the coefficients was evaluated on the confidence levels 90,95 and $99 \%$. With the purpose of characterizing the decadal variability in the ANDD, several methods were used. (1) An 11 years weighted running mean, following the weight scheme employed by Penalba and Vargas (2004). These weights, from the 1st through to the 11 th years in the running window, are $1 / 24,1 / 24,1 / 12$, $1 / 8,1 / 8,1 / 6,1 / 8,1 / 8,1 / 12,1 / 24$ and $1 / 24$, respectively. (2) A wavelet analysis applied on the original series of ANDD. The wavelet analysis provides numerous advantages in comparison to the traditional spectral analysis, as it provides a temporal location of the signal (Pasquini et al. 2006). The mother wavelet chosen for this analysis was the Morlet function (Morlet et al., 1982), which is one of the most employed functions to detect geophysical signals (Foufoula-Georgiou and Kumar, 1994). The significance of the periodicities was evaluated for each time series, using either a white-noise spectrum or a red-noise spectrum, on a confidence level of $95 \%$. The theoretical aspects of the wavelet analysis can be found in the works of Torrence and Compo (1998) and Labat (2005), among others. (3) A cubic polynomial fit. The non-lineal trends and variabilities in the time series were estimated using a cubic polynomial as it provided an adjustment that was not affected by the first and last values of the series. This kind of polynomial adjustment was 
Table I. Numbers, names, locations and record periods of the analysed meteorological stations.

\begin{tabular}{|c|c|c|c|c|}
\hline Number & Station & Latitude $(S)$ & Longitude $(W)$ & Period \\
\hline 1 & Orán & $23^{\circ} 09 \prime$ & $64^{\circ} 19 \prime$ & $1957-2008$ \\
\hline 2 & Salta & $24^{\circ} 51 \prime$ & $65^{\circ} 29 \prime$ & $1926-2008$ \\
\hline 3 & Las Lomitas & $24^{\circ} 42^{\prime}$ & $60^{\circ} 35 \prime$ & $1959-2008$ \\
\hline 4 & Santiago Del Estero & $27^{\circ} 46^{\prime}$ & $64^{\circ} 18 \prime$ & $1931-2008$ \\
\hline 5 & Pcia. Roque Sáenz Peña & $26^{\circ} 45_{\prime}^{\prime}$ & $60^{\circ} 24 \prime$ & $1957-2008$ \\
\hline 6 & Posadas & $27^{\circ} 22 \prime$ & $55^{\circ} 58 \prime$ & $1957-2008$ \\
\hline 7 & La Rioja & $29^{\circ} 23 \prime$ & $66^{\circ} 49 \prime$ & $1941-2008$ \\
\hline 8 & Villa María Del Río Seco & $29^{\circ} 54 \prime$ & $63^{\circ} 41^{\prime}$ & $1931-2008$ \\
\hline 9 & Ceres & $29^{\circ} 53 \prime$ & $61^{\circ} 57 \prime$ & $1931-2008$ \\
\hline 10 & Reconquista & $29^{\circ} 11 \prime$ & $59^{\circ} 42 \prime$ & $1948-2008$ \\
\hline 11 & Bella Vista INTA & $28^{\circ} 26^{\prime}$ & $58^{\circ} 55 \prime$ & $1929-2008$ \\
\hline 12 & Paso De Los Libres & $29^{\circ} 41 \prime$ & $57^{\circ} 09 \prime$ & $1956-2008$ \\
\hline 13 & Villa Dolores & $31^{\circ} 57 \prime$ & $65^{\circ} 08 \prime$ & $1930-2008$ \\
\hline 14 & Córdoba Aero & $31^{\circ} 19 \prime$ & $64^{\circ} 13 \prime$ & $1956-2008$ \\
\hline 15 & Pilar Observatorio & $31^{\circ} 40 \prime$ & $63^{\circ} 53 \prime$ & $1925-2008$ \\
\hline 16 & Sauce Viejo & $31^{\circ} 42 \prime$ & $60^{\circ} 49 \prime$ & $1958-2008$ \\
\hline 17 & Monte Caseros & $30^{\circ} 16^{\prime}$ & $57^{\circ} 39 \prime$ & $1931-2008$ \\
\hline 18 & Mendoza Observatorio & $32^{\circ} 53 \prime$ & $68^{\circ} 51 \prime$ & $1957-2008$ \\
\hline 19 & San Luis & $33^{\circ} 16^{\prime}$ & $66^{\circ} 21 \prime$ & $1951-2008$ \\
\hline 20 & Villa Reynolds & $33^{\circ} 44 \prime$ & $65^{\circ} 23 \prime$ & $1956-2008$ \\
\hline 21 & Río Cuarto & $33^{\circ} 07 \prime$ & $64^{\circ} 14 \prime$ & $1931-2008$ \\
\hline 22 & Marcos Juarez & $32^{\circ} 42 \prime$ & $62^{\circ} 09 \prime$ & $1953-2008$ \\
\hline 23 & Rosario & $32^{\circ} 55 \prime$ & $60^{\circ} 47 \prime$ & 1936-2008 \\
\hline 24 & Gualeguaychú & $33^{\circ} 00 \prime$ & $58^{\circ} 37 \prime$ & $1931-2008$ \\
\hline 25 & Malargüe & $35^{\circ} 30 \prime$ & $69^{\circ} 35 \prime$ & $1956-2008$ \\
\hline 26 & San Rafael & $34^{\circ} 35 \prime$ & $68^{\circ} 24 \prime$ & $1956-2008$ \\
\hline 27 & General Pico & $35^{\circ} 42 \prime$ & $63^{\circ} 45_{\prime}^{\prime}$ & $1956-2008$ \\
\hline 28 & Laboulaye & $34^{\circ} 08 \prime$ & $63^{\circ} 22 \prime$ & $1940-2008$ \\
\hline 29 & Pehuajó & $35^{\circ} 52 \prime$ & $61^{\circ} 54 \prime$ & $1959-2008$ \\
\hline 30 & Junín Aero & $34^{\circ} 33 \prime$ & $60^{\circ} 55 \prime$ & 1959-2008 \\
\hline 31 & Nueve De Julio & $35^{\circ} 27 \prime$ & $60^{\circ} 53 \prime$ & $1931-2008$ \\
\hline 32 & Buenos Aires & $34^{\circ} 35 \prime$ & $58^{\circ} 29 \prime$ & 1909-2008 \\
\hline 33 & Punta Indio & $35^{\circ} 22 \prime$ & $57^{\circ} 17^{\prime}$ & $1957-2008$ \\
\hline 34 & Santa Rosa & $36^{\circ} 34 \prime$ & $64^{\circ} 16^{\prime}$ & $1938-2008$ \\
\hline 35 & Coronel Suarez & $37^{\circ} 26^{\prime}$ & $61^{\circ} 53 \prime$ & $1937-2008$ \\
\hline 36 & Tandil & $37^{\circ} 14 \prime$ & $59^{\circ} 15^{\prime}$ & $1960-2008$ \\
\hline 37 & Dolores & $36^{\circ} 21 \prime$ & $57^{\circ} 44 \prime$ & $1931-2008$ \\
\hline 38 & Mar Del Plata & $37^{\circ} 56^{\prime}$ & $57^{\circ} 35_{\prime}^{\prime}$ & $1951-2008$ \\
\hline 39 & Neuquén & $38^{\circ} 57 \prime$ & $68^{\circ} 08^{\prime}$ & $1957-2008$ \\
\hline 40 & Bahía Blanca & $38^{\circ} 44 \prime$ & $62^{\circ} 10 \prime$ & $1960-2008$ \\
\hline 41 & Bariloche & $41^{\circ} 09 \prime$ & $71^{\circ} 10 \prime$ & $1957-2008$ \\
\hline 42 & Esquel & $42^{\circ} 56^{\prime}$ & $71^{\circ} 09 \prime$ & $1960-2005$ \\
\hline 43 & Trelew & $43^{\circ} 12^{\prime}$ & $65^{\circ} 16 \prime$ & $1959-2005$ \\
\hline 44 & Comodoro Rivadavia & $45^{\circ} 47 \prime$ & $67^{\circ} 30 \prime$ & $1960-2005$ \\
\hline 45 & Puerto Deseado & $47^{\circ} 44 \prime$ & $65^{\circ} 55_{\prime}^{\prime}$ & $1960-2005$ \\
\hline 46 & Río Gallegos & $51^{\circ} 37 \prime$ & $69^{\circ} 17 \prime$ & 1960-2005 \\
\hline
\end{tabular}

used by Minetti et al. (2003) to study annual precipitation in Argentina.

\section{Results}

\subsection{Climatology of dry days}

The average ANDD in the period 1960-2005 is shown in Figure 2, together with the annual precipitation average field for the same period. To bring a broad approach to the climatology of the dry days, harmonic analysis was applied to the climatological monthly means of dry days in order to determine the cycles that describe their annual regime. Variance associated with annual oscillations (the first harmonic) is presented in Figure 3, together with the climatic monthly averages of dry days.

A first insight in Figure 2 showed that the spatial distribution of the isohyets of ANDD resembles the pattern of annual precipitation, with a North-South orientation in the Central-West portion of the country. The most important spatial differences between the climatological values of both variables were located in the 


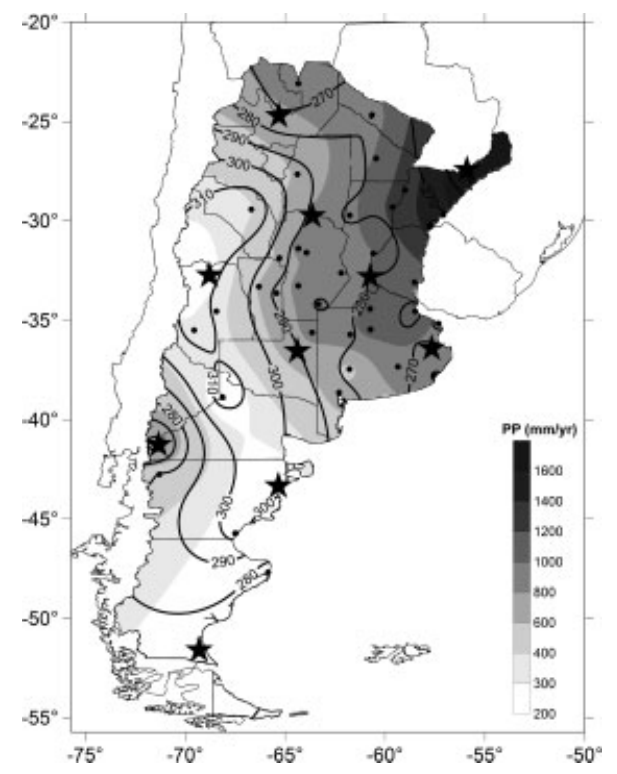

Figure 2. Climatic values of the annual number of dry days (contours) and average annual precipitation ( $\mathrm{mm}$; shaded) for the period 1960-2005. Selected stations in each region are marked with a star.

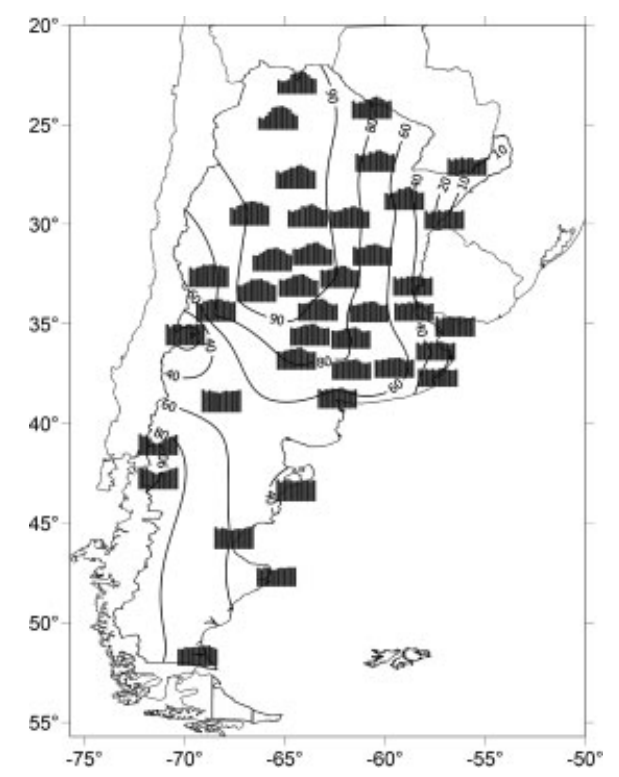

Figure 3. Climatological monthly number of dry days (in bars) and the variance $(\%)$ explained by the annual cycle (first harmonic).

Central-East region and in the Patagonian coast. Maximum values in the ANDD, with more than 300 dry days per year, were placed in the Central-West region of the country, extending in a roughly NW-SE direction from the Central Andes to the Patagonian coast (Figure 2). This arid zone was documented by Bruniard (1982) and Loyarte (1995) and is part of the South American Arid Diagonal, which cover almost one third of the country. The region appears as a combination of mountain rain shadows and the interaction between the limits of the semi-permanent high pressure systems of the Atlantic and Pacific Oceans (Schwerdtfeger, 1976). Precipitation in this region is less than $400 \mathrm{~mm}$ per year. The annual cycle along the arid diagonal is pronounced in the North (Figure 3), with maximum values of dry days during winter season (June-July-August); and has little variations in the South, where the third harmonic becomes more important (results not shown), and maximum values of dry days were recorded during summer (December-January-February). South of the arid diagonal, values between 250 and 280 dry days per year were recorded over the Andean and Southern Patagonia regions (Figure 2). Westerly winds discharge most of their moisture over the Southern Andean region, producing more than $850 \mathrm{~mm}$ per year in Bariloche station [41, Figure 1 and Table I]. The annual cycle dominates this region and most of the precipitation amount is recorded during winter (Castañeda and González, 2008), in agreement with the low values of dry days in that season (Figure 3). Southern Patagonia coast receives less than $300 \mathrm{~mm}$ per year, which tend to occur during summer season (Paruelo et al., 1998) and most of the dry days were recorded during spring (Figures 2 and 3). Northeastern of the arid diagonal, the ANDD varies from 280 to 300 (Figure 2). The behaviour of the dry days showed a marked annual cycle over Central Argentina, with the first harmonic explaining more than $90 \%$ of the variability. On the other hand, the southern stations showed a less prominent annual variation in dry days, with Bahía Blanca [40] explaining less than $60 \%$ of the variance (Figure 3). This decrease is also present in the annual rainfall (Penalba and Vargas, 2004). The highest values of dry days were recorded during winter season, as shown in Figure 3. In the eastern portion of Buenos Aires province, the ANDD lies between 260 and 270 (Figure 2), showing evidence of a possible oceanic influence which is not manifested in the precipitation field. The annual variation in the dry days is little, with the first harmonic explaining less than $40 \%$ of the variance (Figure 3 ). This annual behaviour is in contrast with the one of precipitation amounts (Penalba and Vargas, 1996). Towards Central-Eastern of the country, the second and third harmonics becomes important (results not shown), where also these harmonics becomes important regarding precipitation (Rusticucci and Penalba, 2000). The Northeast region of Argentina recorded the minimum number of dry days per year, characterized with values between 250 and 280 dry days which are uniformly distributed among the year (Figure 3). In the Northwest region, values between 260 and 290 dry days per year are recorded, mostly during winter season. The annual cycle represents more than $90 \%$ of the total variance. This region has a monsoon precipitation regime, with rainy summers and dry winters (Prohaska, 1976). The percentage of variance explained by the annual cycle of climatological monthly precipitation has a maximum (90\%) in this region (Rusticucci and Penalba, 2000). Annual precipitation lies between 600 and $1000 \mathrm{~mm}$, with an SW-NE variation.

To quantify to what extent ANDD and annual precipitation amount are related, correlation analysis between these two variables were performed (Figure 4). There are a good agreement between ANDD and annual precipitation for the period 1960-2005. The correlation 


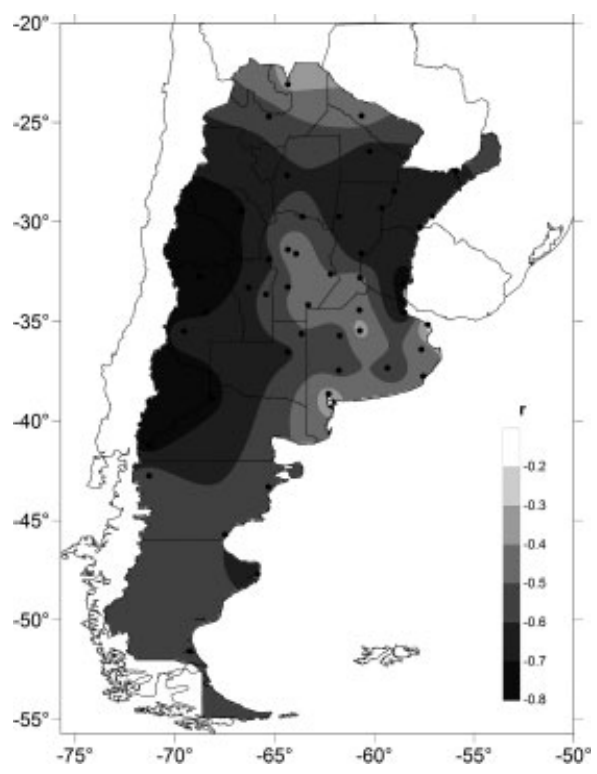

Figure 4. Spatial correlation between the annual number of dry days and the annual precipitation totals.

is negative and significant at the $95 \%$ confidence level in all the country, except for Punta Indio station [33] (Figure 4). The correlation field showed that the highest absolute values are located in the Central-West and Central-North regions. In those regions, much of the variability of the annual precipitation can be explained by the ANDD. The region with lowest correlation coefficients in absolute values is located over an NW-SE diagonal, from the Northern region towards Buenos Aires province.

\subsection{Linear trends in the period 1960-2005}

In most of the locations, the ANDD showed a decrease in the period 1960-2005 (Figure 5), although some stations mainly located in the south of the Buenos Aires province and in the Central-East region indicated a positive trend. Most of the trends were non-significant, specially the ones located in the Central-East and Northern regions. Is this behaviour followed by an increase in annual precipitation totals over the same period, 1960-2005? Almost $90 \%$ of the stations showed positive trends in annual precipitation totals, which $45 \%$ of them were significant at a $90 \%$ level of confidence (not shown). This indicates a partial relationship between those variables, given that some of the precipitation trends could be explained by the increasing frequency of daily extreme events, as shown by Robledo (2007) and Penalba and Robledo (2010). The authors found that the positive trends in the extreme precipitation events were located over the Central and Northern regions of Argentina, and could be responsible for the region of low correlation values between the ANDD and the annual precipitation totals (Figure 4).

The stations with negative and significant values were distributed along the arid diagonal (Figure 5). Thus, increases in precipitation in that region were due to a decrease in the occurrence of dry days (more wet days),

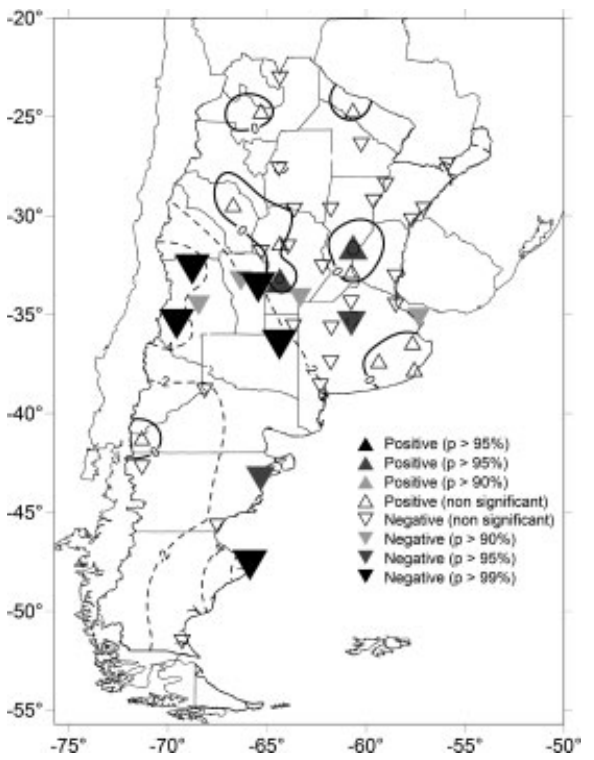

Figure 5. Spatial distribution of trends in the annual number of dry days during the period 1960-2005. Contour lines show the magnitude of trends in dry days per decade.

and the positive trends in extreme events (Robledo, 2007; Penalba and Robledo, 2010). The decreases range from 2 to 6 dry days per decade over the Central-West region and the Patagonian coast (contours in Figure 5). Since there are about 300 dry days per year over the arid diagonal, these trends represent a change of less than $2 \%$. Only two stations showed positive trends, significant at a level of 95\%: Río Cuarto [21] and Sauce Viejo [16], both in the Central portion of the country.

Barros et al. (2000) demonstrated that the positive precipitation trends over Central and Northern Argentina were related to a decrease in the mean meridional gradient of temperature, which implies a displacement to higher latitudes of the Atlantic Subtropical High. Furthermore, Barros et al. (2008) showed that annual precipitation trends during the extreme phases of El Niño Southern Oscillation (ENSO) constitute only a small part of the trends. Both factors could be responsible for the trends in the ANDD given the good agreement between both variables, although further research is needed regarding this topic.

\subsection{Inter-annual and inter-decadal variability}

\subsubsection{Smoothed time series analysis}

Given the climatological features of the dry days, their relationship with the precipitation characteristics and the significant trends present in the country, we selected several stations over Argentina with the purpose to give a broad approach of the different temporal variabilities present in the country. Ten locations were selected to analyse their temporal variations (marked with stars in Figure 2). It should be noted that the historical available records of these selected stations were used, which sometimes differs between stations. To identify different low frequency variabilities, the series of ANDD for these 

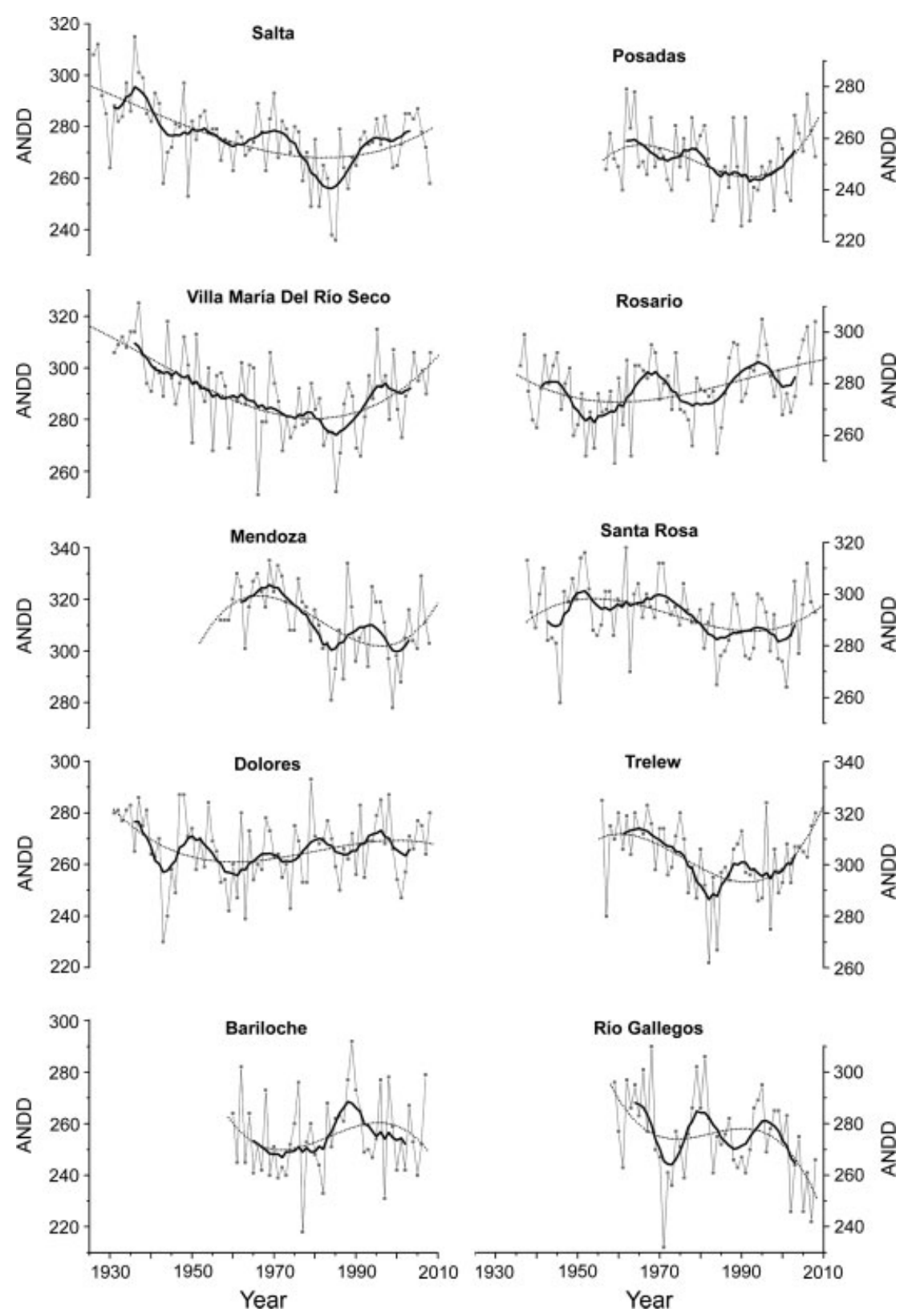

Figure 6. Time series of annual number of dry days for the selected stations (thin line) with a low pass filter (thick line) and a cubic polynomial fit (dashed line).

stations, together with their non-lineal adjustments and 11 years weighted running mean are shown in Figure 6. The non-lineal adjustments were also shown in order to illustrate the long-term oscillations in a clear way.

A tendency towards humid conditions was observed in Salta [2] and in Villa María Del Río Seco [8] stations, from the 1930s until the beginning of the 1990s. Large inter-annual variability and relatively small decadal variability were evident in Villa María Del Río Seco [8]. A very intense humid period, characterized by relatively low values of dry days, was recorded during the 1980s in Salta [2], with surplus of more than $100 \mathrm{~mm}$. Vargas et al. (2002) found positive precipitation anomalies in all the North West region of Argentina. Its maximum intensity was reached during 1985, which was the year that had the minimum ANDD in the record of Salta station [2]. This humid period was also evident in Villa María Del Río Seco [8] and Rosario [23] stations, although with a lesser intensity. This behaviour was detected by indicators like the annual drought index by Minetti et al. (2007). Dolores station [37] showed a trend towards increasing quantities of dry days since the 1950s. Their inter-annual variability was important and showed a considerable amount of humid periods, like the flooding of 2001 (Scarpati et al., 2008), that also was evident in Santa Rosa station [34]. A similar behaviour to that of Dolores station [37] was observed in Rosario [23], but with a more pronounced trend towards dry conditions and a remarkable decadal variability. In Posadas station [6], a high number of dry days was recorded during the 1960s, the first half of the 1970 decade and 2000s. During the 1980s a wet period was registered, that lasted until the end of 
the 1990s. Bravo et al. (2010) showed that during the 1971-1996 period, some part of the North East region of Argentina recorded $22 \%$ more rainfall than the average. This increased the fire frequency in the Chaco forests during dry years, because of the influence of rainfall on fine fuel production for fires. These periods were in agreement with the deviations of precipitation in the northeast part of the country, with a deficit of $150 \mathrm{~mm}$ during the 1970s and a surplus of almost $200 \mathrm{~mm}$ during the 1980s. Bariloche station [41] showed longterm behaviour similar to Rio Gallegos [46], although the later has a pronounced trend to fewer dry days per year. This behaviour is quite opposite to Trelew [43] and Mendoza [18], which are located over the arid diagonal and showed a recent trend towards dry conditions. The non-lineal trend of the ANDD in Rio Gallegos station [46] is remarkable, and decadal variability is apparent.

A great difference was observed between the behaviours of the inter-annual variability of each station. This fact is due to the different precipitation regimes present in the country. In some cases, long-term oscillations described by the non-linear trends showed similar regional behaviours. The negative trends found in Posadas [6], Mendoza [18], Villa María Del Río Seco [8], Santa Rosa [34], Trelew [43] and Río Gallegos [46] stations; and the positive trends found in Rosario [23] and Dolores [37] (Figure 5) manifests as parts of low frequency fluctuations (Figure 6). Moreover, a close view to low frequency fluctuations allows to assess the reversed sign in trend analysis - from decreasing to increasing ANDD - corresponding to the last 20 years of the series, except that of Bariloche and Río Gallegos stations. These trend reversals were also documented by Penalba et al. (2010) for Ceres [9] and Las Lomitas [3] stations, among other locations.

\subsubsection{Analysis of quasi-oscillations}

To identify quasi-oscillations in the selected locations, the Morlet wavelet transform was applied to the ANDD time series described in Figure 6, and the results are shown in Figure 7. Posadas [6] and Trelew [43] showed no significant variabilities in the wavelet analysis and were not included in Figure 7. The differences in the regional behaviours of the ANDD series were reflected in these results, which effectively describe the different climate features of the country. The majority of the stations showed significant periods with values between 10 and 24 years. A significant signal was exhibited between 14 and 24 years for Dolores station [37], which appears interrupted during the second half of the 1960s. This signal had a lower frequency until 1965, and subsequently changed towards higher frequencies between 1970 and 1990. This change was also observed in the corresponding time series (Figure 6). Similarly, a significant period of approximately 24 years was identified in Rosario station [23] during the whole period, which was evident in its time series. This location also showed variabilities between 8 years during the 1980s and between 10 and
14 years during the 1940s and 2000s. Although a large part of the variability fell within the cone of influence, the significant cycles captured and quantified by the method were observed in the series (Figure 6), and were therefore real. Santa Rosa station [34] revealed variabilities between 8 and 20 years in the beginning and end of its time series. Bariloche [41] and Río Gallegos [46] stations showed significant periodicities in the range of approximately 16-24 years. There were also signs of variability in the inter-annual range (7-9 years) in Mendoza station [18], significant from the late-1980s, in Dolores station [37] during the 1940s and during the first half of the 1950s and in Rosario station [23] during the 1980s. Salta [2] and Villa María Del Río Seco [8] showed significant periodicities in the range of 2-4 years, according to a red-noise process. Mendoza station [18] showed an amplification of its time series after 1970s, a fact that is opposite to the behaviour of summer precipitation (Compagnucci et al., 2002). Summer precipitation in the Central-West region of the country possesses low frequency variability in the range of 18-22 years Agosta et al. (1999). Most of the works that studied precipitation periodicities in Argentina used to found the ENSO signal as the most important, mainly in the Central-Northeastern region (Penalba and Vargas, 2004). It is remarkable that this signal is not evident in the ANDD over the region.

Some of the stations showed significant cycles greater than 40 years, which represent long-term trends. On the other hand, it should be noted that these trends can differ from the trends obtained for the period 1960-2005 (Figure 5), because of the difference of years of each analysis.

\section{Conclusions}

The purpose of this study was to use the ANDD to analyse their inter-annual and inter-decadal variability based on a climatology for Argentina. This analysis contributes to understand how precipitation is changing in the region, contrasted with results based on annual precipitation and daily extreme events. A climatology of dry days was performed for the period 1960-2005. The spatial pattern of the climatic ANDD resembles most of the patterns of annual precipitation, not only in their mean values, also in their monthly distribution. The annual cycle is important over the Central and Northern Argentina, while the second and third harmonics are important over the arid diagonal and in the Eastern region. The correlation between ANDD and annual precipitation is negative and significant in most of the country, with the highest absolute values located on the Central-West and Central-North regions. Given that most of the General Climate Models calculate the consecutive dry days as an extreme index, this climatology will be useful for a better interpretation of those outputs.

The territory showed trends towards a decrease in the occurrence if dry days during the period 1960-2005, in agreement to the positive trends in annual precipitation. 

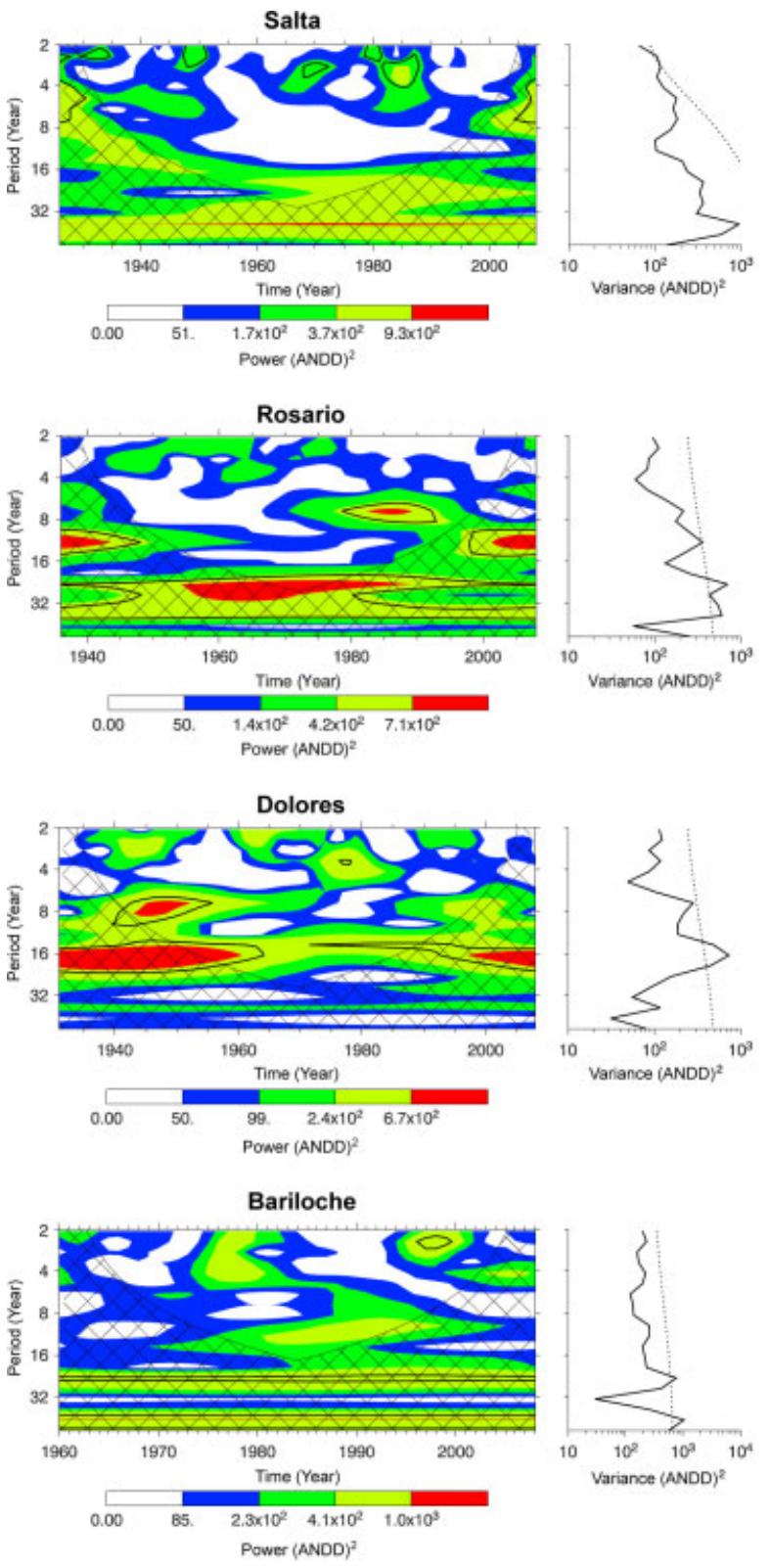
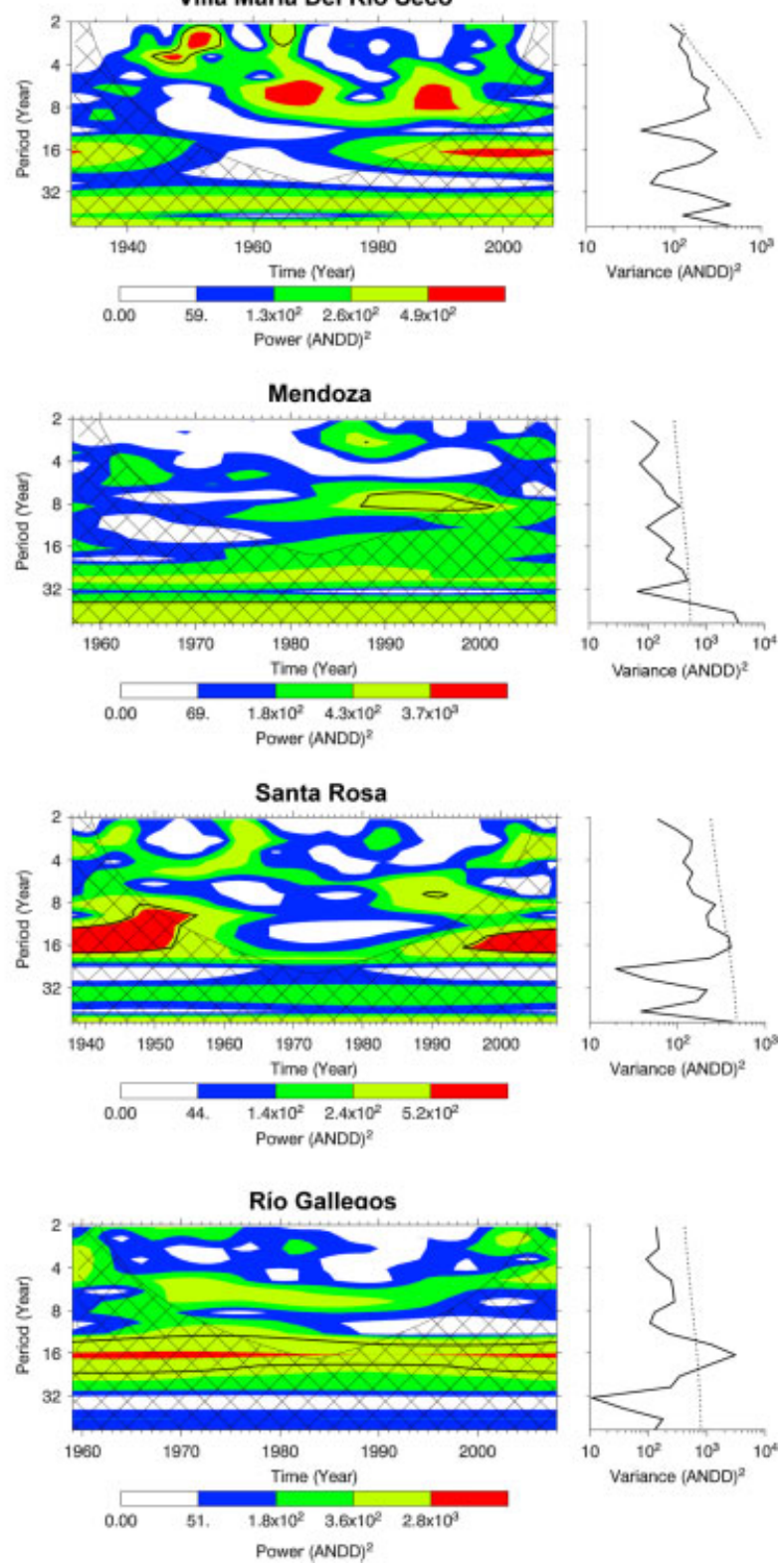

Figure 7. Wavelet transform results of the selected time series of annual number of dry days. The thick contour encloses regions of greater than 95\% confidence for a white-noise or red-noise process. Crosshatched regions on either end indicate the 'cone of influence', where edge effects become important. It should be noted that the $x$-axis scale changes between graphs. This figure is available in colour online at wileyonlinelibrary.com/journal/joc

The significant negative trends indicated a decrease of two to six dry days per decade and were found in the Central-West region and along the Patagonian coast. Several authors also found daily extreme precipitation increases in some regions of the country, which can contribute significantly to the annual precipitation trends. We hypothesize that the positive trends in daily extreme events are responsible for the trends in precipitation totals over the region with lower correlation between the ANDD and annual precipitation.

For the last 80 years periodicities of the ANDD on the inter-annual and inter-decadal scales were identified over Argentina. The most important cycles were observed around 10-24 years, although, depending on the region concerned, variations on the inter-annual scale were also identified. Unlike what happens for the annual accumulated precipitation in the Central-Northwestern region of the country, which had important inter-annual variability (Penalba and Vargas, 2004), the ANDD were modulated by periodicities of lower frequencies. Although trends towards a decrease in the ANDD were identified, in some regions these trends have presented a reversion from the mid-1980s, in agreement with the occurrence of severe droughts in the northern portion of Argentina during the years 1988/1989, 1995/1996, 2003 and 2008/2009. The stations located along the arid diagonal showed an increase of approximately 30 dry days during the 2000 decade, which represents an increment of $10 \%$. On the other hand, the stations located south of the arid diagonal showed recent trends towards less dry days. These facts 
shows the need of a continuous regional monitoring of these hazards, with the objective to optimize the management of the hydrological resources that are getting less and inadequate for the needs of the agricultural sector, the generation of hydropower and human requirements.

\section{Acknowledgements}

The research leading to these results has received funding from the European Community's Seventh Framework Programme (FP7/2007-2013) under Grant Agreement No. 212492 (CLARIS LPB. A Europe-South America Network for Climate Change Assessment and Impact Studies in La Plata Basin); and University of Buenos Aires (UBA 20020100100789 and UBA 20020100200165 grants).

\section{References}

Agosta EA, Compagnucci RH, Vargas WM. 1999. Cambios en el régimen interanual de la precipitación estival en la región CentroOeste argentina. Meteorológica 24: 63-84.

Barros VR, Castañeda ME, Doyle ME. 2000. Recent precipitation trends in Southern South America East of the Andes: an indication of a mode of climatic variability. In Southern Hemisphere paleoand neoclimates, Smolka PP, Volkheimer W (eds). Springer-Verlag Berlin Heidelberg: New York, 187-206.

Barros VR, Doyle ME, Camilloni IA. 2008. Precipitation trends in southeastern South America: relationship with ENSO phases and with low-level circulation. Theoretical and Applied Climatology 93(1-2): 19-33.

Boulanger JP, Martinez F, Penalba OC, Segura E. 2007. Neutral network based daily precipitation generator (NNGEN-P). Climate Dynamics 28: 307-324.

Bravo S, Kunst C, Grau R, Aráoz E. 2010. Fire-rainfall relationships in Argentine Chaco savannas. Journal of Arid Environments 74: 1319-1323.

Bruniard E. 1982. La Diagonal Árida Argentina: un límite climático real. Revista Geográfica 95: 5-20.

Castañeda M, Barros V. 2001. Tendencias de la precipitación en oeste de la Argentina. Meteorológica 26: 5-23.

Castañeda M, González M. 2008. Statistical analysis of the precipitation trends in the Patagonia region in southern South America. Atmósfera 21(3): 303-317.

Compagnucci RH, Agosta EA, Vargas WM. 2002. Climatic change and quasi-oscillations in central-west Argentina summer precipitation: main features and coherent behavior with southern African region Climate Dynamics 18: 421-435.

Cullen BR, Eckard RJ, Mason W, Rawnsley RP. 2009. Incorporating changes in daily rainfall characteristics into future climate scenarios. In Proceedings of the 18th World IMACS/MODISM Congress, Cairns, Australia.

Foufoula-Georgiou E, Kumar P. 1994. Wavelets in Geophysics, Academic Press: New York.

Frich P, Alexander LV, Della-Marta P, Gleason B, Haylock M, KleinTank AMG, Peterson T. 2002. Observed coherent changes in climatic extremes during the second half of the twentieth century. Climate Research 19: 193-212.

Labat D. 2005. Recent advances in wavelet analyses: Part 1. A review of concepts. Journal of Hydrology 314: 275-288.

Logan KE, Brunsell NA, Jones AR, Feddema JJ. 2010. Assessing spatiotemporal variability of drought in the U.S. central plains. Journal of Arid Environments 74: 247-255.
Loyarte MMG. 1995. La diagonale aride argentine: une réalité écologique oscilante. Sécheresse 6(1): 35-44.

Minetti JL, Vargas WM, Poblete AG, Acuña LR, Casagrande G. 2003. Non-linear trends and low frequency oscillations in annual precipitation over Argentina and Chile, 1931-1999. Atmósfera 16: 119-135.

Minetti JL, Vargas WM, Vega B, Costa MC. 2007. Las sequías en la Pampa Humeda: Impacto en la productividad del maíz. Revista Brasileira de Meteorologia 22(2): 218-232.

Mishra AK, Singh VP. 2010. A review of drought concepts. Journal of Hydrology 391: 202-216.

Morlet J, Arens G, Fourfeau E, Giard D. 1982. Wave propagation and sampling theory I: complex signal and scattering in multi-layered media. Geophysics 47(2): 203-221.

Panofsky H, Brier G. 1958. Some Applications of Statistics to Meteorology, College of Mineral Industries, The Pennsylvania State University: Pennsylvania, USA, 224.

Paruelo JM, Beltrán A, Jobbágy E, Sala OE, Golluscio RA. 1998. The climate of Patagonia: general patterns and controls on biotic processes. Ecología Austral 8: 85-101.

Pasquini AI, Lecomte KL, Piovano EL, Depetris PJ. 2006. Recent rainfall and runoff variability in central Argentina. Quaternary International 158: 127-139.

Penalba OC, Llano MP. 2008. Contribución al estudio de las secuencias secas en la zona agropecuaria de Argentina. Meteorológica 32, 33(1, 2): 51-64.

Penalba OC, Robledo FA. 2010. Spatial and temporal variability of the frequency of extreme daily rainfall regime in the La Plata Basin during the $20^{\text {th }}$ century. Climatic Change 98: 531-550.

Penalba OC, Vargas WM. 1996. Climatology of monthly and annual rainfall in Buenos Aires, Argentina. Meteorological Applications 3: $275-282$.

Penalba OC, Vargas WM. 2004. Interdecadal and Interannual variations of annual and extreme precipitation over central-northeastern Argentina. International Journal of Climatology 24(12): 1565-1580.

Penalba OC, Rivera JA, Bettolli ML. 2010. Trends and periodicities in the annual amount of dry days over Argentina, looking towards the climatic change. Options Méditerranéennes Series A: Mediterranean Seminars No. 95: 27-33.

Prohaska F. 1976. The climate of Argentina, Paraguay and Uruguay. In World Survey of Climatology, Schwerdtfeger W (ed). Elsevier Scientific Publishing Company: Amsterdam/Oxford/New York, 13-72.

Robledo FA. 2007. Régimen estacional de la lluvia diaria en el Sudeste de Sudamérica. Cuantificación del cambio en la segunda mitad del siglo 20, M.Sc. dissertation, University of Buenos Aires.

Rusticucci MM, Penalba OC. 2000. Interdecadal changes in precipitation seasonal cycle over South America. Relationship with surface temperature. Climate Research 16: 1-15.

Scarpati OE, Forte Lay JA, Capriolo AD. 2008. La inundación del año 2001 en la Provincia de Buenos Aires, Argentina. Mundo Agrario 9 (17), http://redalyc.uaemex.mx/src/inicio/ArtPdfRed.jsp?iCve= 84511268005. ISSN 1515-5994.

Solomon S, Qin D, Manning M, Chen Z, Marquis M, Averyt KB, Tignor M, Miller HL. 2007. Climate change 2007: The Physical Science Basis, Cambridge University Press: Cambridge, United Kingdom and New York, USA.

Schwerdtfeger W. 1976. Climates of Central and South America. In World Survey of Climatology, Schwerdtfeger W (ed). Elsiever Scientific Publishing Company: Amsterdam/Oxford/New York.

Torrence C, Compo GP. 1998. A practical guide to wavelet analysis. Bulletin of the American Meteorological Society 79: 61-78.

Vargas W, Minetti J, Poblete A. 2002. Low-frequency oscillations in climatic and hydrological variables in southern South America's tropical-subtropical regions. Theoretical and Applied Climatology 72: 29-40.

Zhai L, Feng Q. 2009. Spatial and temporal pattern of precipitation and drought in Gansu Province, Northwest China. Natural Hazards 49: $1-24$. 